\title{
PROSES PEMBELAJARAN PENDIDIKAN ANAK USIA DINI BERBASIS PENDEKATAN KI HAJAR DEWANTARA
}

\author{
Oleh : \\ Ni Ketut Srie Kusuma Wardhani \\ Universitas Hindu Negeri I Gusti Bagus Sugriwa Denpasar \\ e-mail: sriekusuma58@gmail.com
}

Diterima 6 September 2021, direvisi 20 September 2021, diterbitkan 1 Oktober 2021

\begin{abstract}
Abstrak
Pendidikan anak usia dini sesungguhnya adalah tanggung jawab bersama antara keluarga, masyarakat dan pemerintah. Sekolah sebagai pembantu kelanjutan pendidikan dalam keluarga, sebab pendidikan yang pertama dan utama diperoleh anak ialah dalam keluarga. Keluarga sebagai satuan unit sosial terkecil merupakan lingkungan pendidikan yang paling utama dan pertama, dalam arti keluarga merupakan lingkungan yang paling bertanggung jawab mendidik anak-anaknya. Pendidikan yang diberikan orang tua seharusnya memberikan dasar bagi pendidikan, proses sosialisasi dan kehidupannya di masyarakat. Metode dalam Penelitian ini merupakan Metode Kajian Pustaka yang bertujuan untuk menelaah pendekatan Pembelajaran yang digunakan pada Ki Hadjar Dewantara. Hasil dari telaah Pustaka menunjukkan bahwa menurut Ki Hadjar Dewantara, Sistem among yaitu metode pembelajaran dan pendidikan yang berdasarkan pada asih, asah dan asuh (care and dedication based on love). Sistem Among tersebut dijelaskan dalam tiga kalimat sebagai berikut: Ing Ngarso Sing Tulodo, Ing Madya Mangun Karso, Tut Wuri Handayani, Sistem among yang dikemukakan sangat cocok untuk diterapkan pada anak - anak yang sudah masuk dalam pendidikan sekolah dasar antara kelas 1 sampai dengan kelas 3. karena pada tahapan ini anak harus diberikan motivasi dan membangkitkan kemauan sehingga anak terpacu untuk mandiri. Konsep ini juga dapat digunakan dalam membangun rasa percaya diri dan pembentukan karakter anak.
\end{abstract}

Kata Kunci: Pendekatan Ki Hadjar Dewantara, Proses Pembelajaran Pendidikan Anak Usia Dini.

\section{Abstract}

Early childhood education is actually a shared responsibility between families, communities and governments. School as a continuation of education in the family, because the first and foremost education children get is in the family. The family as the smallest social unit is the most important and first educational environment, in the sense that the family is the environment most responsible for educating their children. The education provided by parents should provide the basis for education, the socialization process and life in society. The method in this study is a library study method that aims to examine the learning approach used in Ki Hadjar Dewantara. The results of the literature review show that according to Ki Hadjar Dewantara, the Among system is a method of learning and education based on care and dedication based on love. The among system is explained in three sentences as follows: Ing ngarso sing tulodo, Ing madya mangun karso, Tut wuri handayani, The among system is very suitable to be applied to children who have entered elementary school education between grades 1 to grade 3. because at this stage the child must be motivated and aroused the will so that the child is encouraged to be independent. This concept can also be used in building selfconfidence and character building for children. 


\section{PENDAHULUAN}

Usia dini (0-8 tahun) merupakan usia yang sangat menentukan, dalam pembentukan karakter dan kepribadian seorang anak. Usia dini sangat menentukan pertumbuhan dan perkembangan manusia selanjutnya. Sebab, di usia ini dasar-dasar kepribadian anak telah terbentuk. Pada masa itu juga, anak-anak mengalami salah satu krisis yang disebut krisis pembentukan dasar kepribadian. Jika mereka mendapat pendidikan yang benar akan terbentuk dasar-dasar kepribadian yang kuat. Sebaliknya, jika mendapat pendidikan yang salah maka akan terbentuk dasar kepribadian yang tidak baik.

Pendidikan anak usia dini sesungguhnya adalah tanggung jawab bersama antara keluarga, masyarakat dan pemerintah. Sekolah sebagai pembantu kelanjutan pendidikan dalam keluarga, sebab pendidikan yang pertama dan utama diperoleh anak ialah dalam keluarga. Keluarga sebagai satuan unit sosial terkecil merupakan lingkungan pendidikan yang paling utama dan pertama, dalam arti keluarga merupakan lingkungan yang paling bertanggung jawab mendidik anakanaknya. Pendidikan yang diberikan orang tua seharusnya memberikan dasar bagi pendidikan, proses sosialisasi dan kehidupannya di masyarakat. Dikatakan demikian karena sejak kelahirannya anak berada pada lingkungan dan di bawah asuhan orangtuanya. Pola sikap, perilaku, dan nilai-nilai yang ditanamkan orangtua kepada anak melalui pengasuhannya itu merupakan landasan fundamental bagi perkembangan kepribadian dan tingkah laku anak selanjutnya. Dalam hal ini keluarga tetap menjadi kelompok pertama (primary group) tempat meletakkan dasar kepribadian di dalam keluarga. Orang tua memegang peranan membentuk sistem interaksi yang intim dan berlangsung lama ditandai oleh loyalitas pribadi, cinta kasih dan hubungan yang penuh kasih sayang. Peran orangtua adalah dengan membenahi mental anak. Terbentuknya kepribadian dan kreativitas anak merupakan modal bagi penyesuaian diri anak dan lingkungannya, dan tentunya memberikan dampak bagi kesejahteraan keluarga secara menyeluruh.

Manusia adalah entitas yang akan terus bertumbuh dan berkembang tanpa henti, sebab salah satu tanda atau kriteria dari makhluk hidup adalah tumbuh dan berkembang. Dengan kata lain dalam konteks pengertian ini, manusia tidak memiliki pilihan untuk berhenti berkembang dalam kondisi apapun. Pilihan kehidupan hanya mengenal dua istilah tumbuh atau mati, berkembang atau tidak berkembang; sebagaimana semboyan para pejuang kemerdekaan mengatakan "merdeka atau mati". Realitas ini mendorong manusia untuk berusaha menjaga kemampuan bertahan hidupnya dengan berbagai cara dan metode yang berubah-ubah dari waktu ke waktu sesuai dengan stimulus dan kontekstualisasi stimulus tersebut. Langkah awal yang harus dilakukan untuk menghadapi semua masalah itu harus dipersiapkan sejak manusia kecil hingga dewasa nanti. Pendidikan anak usia dini merupakan tahap awal yang sangat penting untuk diterapkan dan dilaksanakan. Inilah peletak dasar pentingnya pendidikan usia dini. Sejak dini anak harus diberikan berbagai ilmu (dalam bentuk berbagai rangsangan/ stimulan). Mendidik anak pada usia ini ibarat membentuk ukiran di batu yang tidak akan mudah hilang, bahkan akan membekas selamanya. Artinya, pendidikan pada anak usia dini akan sangat membekas hingga anak dewasa. Pendidikan pada usia dini adalah peletak dasar pendidikan selanjutnya. Keberhasilan pendidikan pada usia dini ini sangat berperan besar bagi keberhasilan anak di masa - masa selanjutnya.

Sehingga, dalam membuat Model Pendidikan yang tepat bagi anak usia dini pembelajaran harus berpusat pada anak. Artinya, proses pembelajaran disesuaikan 
dengan perkembangan dan keadaan anak usia dini. Maka dalam tulisan ini akan dibahas mengenai proses pembelajaran Pendidikan anak usia dini berbasis pendekatan dari Ki Hajar Dewantara.

\section{METODE}

Metode Penelitian yang dugunakan merupakan Metode Kajian Pustaka, dimana data diperoleh melalui telaah Pustaka dari berbagai buku mengenai Konsep dan pendekatan Pembelajaran Menurut Ki Hadjar Dewantara. Adapun Tujuan dari Penelitian ini adalah menelaah Pendekatan pembelajaranan dan Metode Pendidikan yang dikemukakan oleh $\mathrm{Ki}$ Hadjar Dewantara dan aplikasinya di sekolah atau di dunia Pendidikan.

\section{PEMBAHASAN}

Menurut Ki Hajar Dewantara, metode pendidikan yang sesuai dengan sistem pendidikan ini adalah sistem among yaitu metode pembelajaran dan pendidikan yang berdasarkan pada asih, asah dan asuh (care and dedication based on love). Yang dimaksud dengan manusia merdeka adalah seseorang yang mampu berkembang secara utuh dan selaras dari segala aspek kemanusiaannya dan yang mampu menghargai dan menghormati kemanusiaan setiap orang. Selain itu, pembelajaran yang diberikan kepada anak didik tidak bersifat paksaan bahkan perilaku memimpin kadang tidak perlu dilakukan. Sebagai gantinya, para pendidik harus bersikap ngemong atau among. Para guru seharusnya tidak membelajarkan pengetahuan mengenai dunia secara dogmatik. Sebaliknya, mereka hanya berada dibelakang anak didik sambil memberi dorongan untuk maju, secara halus mengarahkan ke jalan yang benar, dan mengawasi kalau - kalau anak didik menghadapi bahaya atau rintangan. Anak didik harus memiliki kebebasan untuk maju menurut karakter masing - masing dan untuk mengasah hati nuraninya.

Pemahaman tentang PAUD menurut Ki Hajar Dewantara, yang menjadi ciri khas dari PAUD adalah Budi Pekerti dan Sistem Among.

1. Budi Pekerti, Materi yang paling penting diberikan kepada anak usia dini adalah pendidikan Budi Pekerti. Bentuknya bukan mata pelajaran budi pekerti, tetapi menanamkan nilai, harkat,dan martabat kemanusiaan, nilai moral watak, dan pada akhirnya pembentukan manusia yang berkepribadian. Budi Pekerti bertujuan untuk mengatur kehidupan manusia. Pendekatan yang baik dan tepat dalam menanamkan budi pekerti pada PAUD menurut aliran ini adalah dengan memberikan contoh teladan, cerita atau dongeng, dan permainan. Dengan pendekatan tersebut kita dapat mendidik anak tentang budi pekerti sedangkan sang anak tidak merasa bahwa sikapnya sedang dibentuk. Kreativitas dan inovasi guru dituntut dalam proses pembelajaran untuk mendidik, khususnya pembentukan sikap melalui pelajaran yang sedang diberikan.

2. Sistem Among, inti dari sistem among yang dikemukakan oleh $\mathrm{Ki}$ Hajar Dewantara dalam Napitupulu (2001;15-16) adalah :

- Ing ngarso sing tulodo, artinya jika pendidik berada di depan wajib memberikan teladan bagi anak didik. Posisi ini sebaliknya lebih banyak diberikan kepada anak usia dini, tidak perlu banyak nasehat, petuah dan ceramah.

- Ing madya mangun karso, artinya jika pendidik berada di tengah - tengah harus lebih banyak membangun atau membangkitkan kemauan sehingga anak mempunyai kesempatan untuk mencoba berbuat sendiri. Anak usia dini sudah dapat mengerjakan, namun lebih tepat setelah taman kanak-kanak teladan pendidik masih diperlukan. 
- Tut Wuri Handayani, artinya jika pendidik di belakang wajib memberi dorongan dan memantau agar anak mampu bekerja sendiri.

Pada sistem among pendidik haruslah mengikuti dari belakang, tetapi memberikan arahan atau bimbingan juga. Anak di beri kebebasan, tetapi di ikuti perkembangannya.

Penerapan dalam Pendidikan, Ki Hajar Dewantara mengutarakan tentang alat pendidikan yang dapat digunakan dalam mendorong keberhasilan proses pendidikan yaitu : Motivasi (dorongan), memberikan dorongan kepada anak baik dari luar maupun dari dalam agar anak memiliki keinginan untuk melakukan kegiatan baik verbal maupun non verbal. Reinforcement (penguatan), memberikan pengulangan kepada anak baik dari luar maupun dari dalam agar anak mengetahui dan memahami tentang sesuatu yang diberikan oleh guru dalam proses pembelajaran. Reward (penghargaan), ketika anak sudah mampu menyelesaikan tugas lebih dulu dengan baik, maka pendidik memberikan penghargaan kepada anak dengan memberikan acungan jempol atau memberikan tanda bintang dan lingkaran penuh. Punishment (sangsi sosial), ketika anak membuang sampah sembarangan sebagai sangsinya anak disuruh mengambil sampah dan membuangnya ketempat sampah.

Selain itu, atas dasar keluhuran budi, tugas pendidik yang utama adalah mengembangkan cipta, yaitu pengembangan kognitif atau daya pikir, mengembangkan rasa, yaitu pengembangan sikap perilaku/ afektif. Mengembangkan karsa, yaitu pengembangan psikomotorik/ ketrampilan.

Pembelajaran pada anak dilakukan secara terus menerus/ berkesinambungan, menerapkan konsep belajar melalui bermain, menerapkan konsep belajar dengan cara pemberian contoh atau teladan dengan metode bercerita atau mendongeng.
Sedangkan sistem among yang dikemukakan sangat cocok untuk diterapkan pada anak - anak yang sudah masuk dalam pendidikan sekolah dasar antara kelas 1 sampai dengan kelas 3 . karena pada tahapan ini anak harus diberikan motivasi dan membangkitkan kemauan sehingga anak terpacu untuk mandiri. Konsep ini juga dapat digunakan dalam membangun rasa percaya diri dan pembentukan karakter anak.

Pendekatan dalam PAUD yang dapat di gunakan terkait dengan model pendidikan dia atas yaitu (1) Berorientasi pada Kebutuhan anak, sesuai dengan perkembangan jaman saat ini, dibutuhkan kegiatan pembelajaran yang memberikan kemampuan (skill) anak dari segi IPTEK serta dapat menguasai lebih dari satu bahasa. Kegiatan pembelajaran pada anak usia dini juga senantiasa berorientasi kepada kebutuhan anak untuk mendapatkan layanan pendidikan, kesehatan dan gizi yang dilaksanakan secara integratif dan holistik. Contoh kegiatan kemandirian, seperti : makan sendiri, mengenakan dan melepaskan pakaian, mengeluarkan dan menyimpan mainan, dan berkomunikasi dengan guru untuk menyampaikan maksudnya. Setiap anak memiliki potensi yang berbeda, baik potensi diri ataupun lingkungannya. Selain itu, tingkat kebutuhannya pun berbeda. Contohnya, anak yang memiliki kemampuan diatas rata - rata dapat diberikan pengayaan untuknya, sedangkan anak yang memiliki kemampuan di bawah rata - rata diberikan bimbingan sesuai dengan kemampuan yang akan dicapainya. (2) Berorientasi pada Perkembangan Anak, perkembangan merupakan suatu proses yang bersifat kumulatif, artinya perkembangan terdahulu akan menjadi dasar bagi perkembangan selanjutnya. Oleh sebab itu, apabila terjadi hambatan pada perkembangan terdahulu maka perkembangan selanjutnya cenderung akan mendapat hambatan. Berdasarkan teori perkembangan anak, diyakini bahwa setiap anak lahir dengan lebih dari satu bakat. Bakat tersebut bersifat 
potensial dan ibaratnya belum muncul di atas permukaan air. Untuk itulah anak perlu diberikan pendidikan yang sesuai dengan perkembangannya dengan cara memperkaya lingkungan bermainnya. Itu berarti orang dewasa perlu memberi peluang kepada anak untuk menyatakan diri, berekspresi, berkreasi, dan menggali sumber-sumber terunggul yang tersembunyi dalam diri anak. (3) $\boldsymbol{A} \boldsymbol{U} \boldsymbol{D}$ Belajar melalui Bermain, bermain adalah kegiatan yang mereka lakukan sepanjang hari karena bagi anak bermain adalah hidup dan hidup adalah permainan. Anak Usia Dini tidak membedakan antara bermain, belajar, dan bekerja. Anak - anak umumnya sangat menikmati permainan dan akan terus melakukannya di manapun mereka memiliki kesempatan. Bermain adalah dunia anak melalui kegiatan bermain anak mengembangkan berbagai aspek kecerdasannya jamak. Permainan edukatif dapat membantu mengoptimalkannya. Melalui bermain anak juga dapat mengenal siapa diri dan lingkungannya, dan tak kalah penting anak dikenalkan kepada Tuhannya melalui mahluk ciptaannya. (4) Pembelajaran Aktif, Kreatif, Efektif, dan Menyenangkan (PAKEM), menurut UU RI No. 20 tahun 2003 tentang Sistem Pendidikan Nasional, Pasal 4, ayat 4 menyatakan bahwa : pendidikan diselenggarakan dengan memberi keteladanan, membangun kemauan, dan mengembangkan kreativitas peserta didik dalam proses pembelajaran. Pembelajaran yang aktif, dimaksudkan bahwa dalam proses pembelajaran guru harus menciptakan suasana sedemikian rupa sehingga anak aktif bertanyam mempertanyakan, dan mengemukakan gagasan. Belajar harus merupakan suatu proses aktif dari anak dalam membangun pengetahuannya, bukan hanya proses pasif yang hanya menerima penjelasan dari guru tentang pengetahuan. Kreatif, artinya memiliki daya cipta, memiliki kemampuan untuk berkreasi (Silberman,1996:9). Peran aktif anak dalam proses pembelajaran akan menghasilkan generasi yang kreatif, artinya generasi yang mampu menghasilkan sesuatu untuk kepentingan dirinya dan orang lain. Efektif, pembelajaran yang efektif terujud karena pembelajaran yang dilaksanakan dapat menumbuhkan daya kreatif bagi anak sehingga dapat membekali anak dengan berbagai kemampuan. Menyenangkan, perlu tercipta suasana pembelajaran yang menyenangkan sehingga anak memusatkan perhatiannya secara penuh pada belajar sehingga waktu curah perhatiannya tinggi. Menurut hasil penelitian, tingginya perhatian anak terbukti dapat meningkatkan hasil belajar. Kondisi yang menyenangkan, aman, dan nyaman akan mengaktifkan bagian neocortex (otak berpikir) dan mengoptimalkan proses belajar dan meningkatkan kepercayaan diri anak. Suasana kelas yang kaku, penuh beban, guru galak akan menurunkan fungsi otak menuju batang otak dan anak tidak bisa berpikir efektif, reaktif, atau agresif.

Penerapan sembilan pilar yang harus dilakukan oleh pendidik sebagai pengganti keluarga. Sembilan pilar itu adalah, pertama, cinta kepada Tuhan dan semesta beserta isinya. Hal ini bisa diwujudkan dengan sering mengajak anak bepergian ke alam bebas sambil menerangkan dan menjelaskan seluruh benda-benda yang ada di alam. Pastikan juga anak mengerti kalau semua benda-benda itu ada yang menciptakan dan mengatur keadaan mereka, yaitu Tuhan. Pilar kedua, menumbuhkan rasa tanggung jawab, kedisiplinan, dan kemandirian. Cara pendidikan ini tidak perlu seperti pendidikan militer yang diterapkan dengan keras dan penuh paksaan. "Biarkan anak memahami sifat-sifat dari hal-hal yang kecil, seperti membereskan mainan mereka sendiri setelah selesai digunakan atau belajar sikat gigi sendiri sejak kecil,". Pilar ketiga, yaitu kejujuran. Ajak anak berkata apa adanya, tidak ada yang ditutup-tutupi dan berani mengatakan apa yang dipikirkan atau dirasakannya. Pilar keempat adalah hormat dan santun. Sikap ini bisa dimulai dengan mengajarkan cara memperlakukan 
adik atau kakak atau teman main anak-anak sesuai dengan keadaan dan kondisi yang dihadapi. Kemudian pilar kelima yaitu kasih sayang, kepedulian, dan kerja sama. Dapat dirangsang dengan bermain bersama-sama anggota keluarga dengan model permainan membangun bangunan pasir atau membuat rumah-rumahan dari mainan plastik. Pilar keenam melingkupi percaya diri, kreatif, kerja keras, dan pantang menyerah. Implementasi aspek ini bisa dikembangkan dengan permainan yang dilakukan seperti membentuk karakter pada pilar kelima. Pilar ketujuh adalah keadilan dan kepemimpinan. Bisa juga diajarkan melalui membaca atau dibacakan ceritacerita para raja yang mencerminkan sikap adil dalam memimpin. Pilar kedelapan dan kesembilan, yaitu sikap baik dan rendah hati serta toleransi, cinta damai, dan persatuan, dapat dipatrikan kepada anak melalui kegiatan bersifat kompetitif dan kreatif yang mengajarkan anak bersikap sportif terhadap apa pun hasil kegiatan tersebut.

\section{SIMPULAN}

Sistem among yaitu metode pembelajaran dan pendidikan yang berdasarkan pada asih, asah dan asuh (care and dedication based on love). Sistem among tersebut dijelaskan dalam tiga kalimat sebagai berikut:

- Ing ngarso sing tulodo, artinya jika pendidik berada di depan wajib memberikan teladan bagi anak didik. Posisi ini sebaliknya lebih banyak diberikan kepada anak usia dini, tidak perlu banyak nasehat, petuah dan ceramah.

- Ing madya mangun karso, artinya jika pendidik berada di tengah - tengah harus lebih banyak membangun atau membangkitkan kemauan sehingga anak mempunyai kesempatan untuk mencoba berbuat sendiri. Anak usia dini sudah dapat mengerjakan, namun lebih tepat setelah taman kanak-kanak teladan pendidik masih diperlukan.

- Tut wuri handayani, artinya jika pendidik di belakang wajib memberi dorongan dan memantau agar anak mampu bekerja sendiri.

Sistem among yang dikemukakan sangat cocok untuk diterapkan pada anak - anak yang sudah masuk dalam pendidikan sekolah dasar antara kelas 1 sampai dengan kelas 3. karena pada tahapan ini anak harus diberikan motivasi dan membangkitkan kemauan sehingga anak terpacu untuk mandiri. Konsep ini juga dapat digunakan dalam membangun rasa percaya diri dan pembentukan karakter anak.

\section{DAFTAR PUSTAKA}

Abidin, Zainal, 2000. Filsafat Manusia: Memahami Manusia Melalui Filsafat, Bandung: Remaja Rosdakarya,

Dewantara, Ki Hadjar. 1977. Bagian Pertama: Pendidikan. Cetakan kedua. Yogyakarta: Majelis Luhur Persatuan Taman Siswa.

Roopnarine, Jaipul L. James E. Johnson. 2005. Approach to Early Childhood Education 4th Edition. Ohio: Merrill Prentice Hall.

Sardy, Martin, 1985.Pendidikan Manusia, Bandung: Alumni

Sujiono, Yuliani Nurani. 2009. Konsep Dasar Pendidikan Anak Usia Dini. Jakarta: PT. Indeks.

http://parenting.pustaka-lebah.Model Pendidikan Anak Usia Dini.com (diambil pada hari Selasa, 29 Januari 2021). 